\title{
Effect of Addition of Selenium-Enriched Bean Sprouts Powder in Egg Laying Hen Feed
}

\author{
Myongdok Im, Hakchan Oh, Yongchol Ri, Kuangchol Kim, Dongchol Jong, Hochol Kim \\ Department of Veterinary Medicine and Animal Husbandry, Pyongyang University of Agriculture, Pyongyang, \\ DPR of Korea
}

\begin{abstract}
Article Info

Volume 8, Issue 3

Page Number: 121-128

Publication Issue :

May-June-2021

\section{Article History}

Accepted : 12 May 2021

Published: 22 May 2021

Although selenium was considered an essential trace element in the early 1970s, it is now widely used as a biological effect, and research projects are also actively underway. In the production process of selenium-enriched eggs that can meet people's demand for selenium, this article specifically analyzed the effects of different levels of selenium-enriched bean sprouts powder on the laying performance and egg quality of laying hens. First of all, adding selenium-enriched bean sprouts powder(a kind of organic selenium) to the basal diet fed for a long time(20weeks) will affect the egg laying rate and feed intake, egg weight, egg shape index, and eggshell strength, thickness of eggshell. Next, we analyzed the accumulation of selenium in eggs, breast muscles, liver, skin and kidneys after feeding organic selenium. Results when $15^{\sim} 22.5 \mathrm{~g} / \mathrm{kg}$ selenium-enriched bean sprouts powder(selenium content $40 \mathrm{mg} / \mathrm{kg}$ ) was added to the basal diet fed, the egg laying rate, feed intake, egg weight, eggshell strength and eggshell thickness respectively increased by $100.6 \sim 102.9 \%, 101.3^{\sim} 102.3 \%, 117.1^{\sim} 117.6 \%$ and $105.6 \sim 108.3 \%$, and the selenium content in eggs increased by $197.7^{\sim 206.9 \%}$. Selenium is obviously deposited on the eggs, breast muscles and skin of laying hens. Therefore, in the production process of selenium-enriched eggs, adding selenium-enriched bean sprouts powder not only increased the production efficiency of eggs, but also increased double the selenium content in eggs. From the 15th day of the laying test, selenium-enriched eggs can be obtained.
\end{abstract}

Keywords : laying hens, selenium-enriched bean sprouts, organic selenium, egg quality

\section{INTRODUCTION}

In recent years, from the perspective of meeting people's demand for selenium and improving egg quality, the production of selenium-enriched eggs has attracted the attention of many scholars. In the production method, the original inorganic selenium is converted to organic selenium, such as selenomethionine(Se-Met) or yeast selenium.

In 1817, the chemist J.J. Berzelius Griffiths et al(2006) first discovered the inorganic element selenium in the smelting process. First, he studied from the 
perspective of toxic substances[1]. Researchers such as Rotmck discovered selenium in the composition of glutathione peroxidase in the early 1970s. Since then, selenium has been transformed into a beneficial element, and intensive research has begun. People gradually deepened their understanding of this, and its value gradually became clear[2]. Although the content of selenium in plants and animals is very low, its effect is very high. Selenium is an essential element for human health. It is considered the most nutritious element in the 21st century. It is regarded as the "longevity element" and "the king of anticancer". The trace element selenium is closely related to human health and has powerful functions, mainly cellular antioxidants, radiation prevention and immune enhancement, toxin decomposition, improve children's intelligence, promote development, and can also play a role in preventing cardiovascular and cerebrovascular diseases and anti-cancer.[3,4].

Selenium plays an important role in poultry nutrition, especially commercial poultry, which uses modern chicken genes with high egg production and high growth rates. This increase in productivity makes poultry more susceptible to various stress. Therefore, in modern poultry production, it is very important to prevent selenium deficiency and maximize production performance by meeting the demand for selenium. Especially under commercial conditions, selenium demand levels have increased significantly due to related pressures[5]. Selenium is closely related to daily weight gain, egg laying rate, fertilization rate, hatching rate, and immunity[6]. Selenium cannot be synthesized in the body and can only be consumed through food.[7]

As people realize the importance of selenium supplementation, more and more sources and absorption methods are submitted, and they have gone through the development process of the fourth generation. The first generation of inorganic selenium is sodium selenite, which is $100 \%$ inorganic selenium. Due to its severe toxicity to the human body, it has been eliminated from the market (in Japan and the
United States, its use has been banned since 1993). The second-generation organic selenium is artificially synthesized by adding inorganic selenium (sodium selenite) as a solvent to yeast and barley malt after fermentation, and through a biological transformation. At present, hundreds of factories have led the technology. The third-generation pure natural plant organic selenium is produced due to the side effects of inorganic selenium, which is the basic requirement of the human body to supplement natural organic selenium. Currently, many plant selenium treatment technologies have emerged. The development of the fourth generation of natural animal organic selenium is based on the fact that the selenium supplementation effect in the meat and eggs of animals fed with selenium is significantly better than that of inorganic selenium or plant selenium. Selenium in selenium-enriched eggs and seleniumenriched livestock meat mainly exists in the form of seleno-cysteine, which is present in seleno-albumin and protein. Since protein is absorbed in the small intestine in the form of dipeptides or tripeptides, organic selenium present in food can be better absorbed and utilized by the human body than inorganic selenium[8].

Adding selenium to feed is a general trend in the poultry industry. In the European Union, the use amount of selenium additives is $0.5 \mathrm{mg}$ per kilogram of mixed feed, and the maximum allowable content in the United States is $0.3 \mathrm{mg}$ per kilogram[9]. According to the survey data in 2002, about 40 countries in the world suffer from selenium deficiency. Therefore, selenium supplementation is gradually receiving attention and is considered to be of great significance to animal production. At present, the World Health Organization and NRC have listed selenium as an essential trace element for the human body[10].

Eggs are the main agricultural products in daily life and the main source of protein intake. Research on eggs enriched in selenium is not only good for supplementing trace elements, but the selenium in eggs is also a kind of organic selenium, which is good 
for the body to absorb. Therefore, the study of selenium-enriched eggs is of great significance[11].

Currently, most selenium-enriched eggs are produced through biotransformation, that is, by adding selenium to feed or water. By increasing the selenium content in the laying hens and forming a new dynamic balance of the organism through tissue circulation, the selenium content in the reproductive system is maximized, and selenium is transferred and deposited in the eggs[12]. Many researchers have found that increasing the concentration of inorganic and organic selenium in feed will increase the selenium content in whole eggs. Yeast selenium or seleno-methionine(Se-Met) is more effective than sodium selenate[13].

The sources and levels of selenium added in daily feed are different, and due to the synergy between trace elements, the selenium content in the produced eggs is very different. The selenium content in ordinary eggs is low, with an average of $10^{\sim} 18 \mu \mathrm{g} / \mathrm{egg}$, while the selenium content in selenium-enriched eggs is $30 \sim 50 \mu \mathrm{g} / \mathrm{egg}[14]$. According to the results of the study, selenium-enriched eggs increase the protein viscosity, the yolk is dark yellow, the cholesterol content in the eggs is as low as $21.4 \%$, and the selenium content increases by $31.6 \%$, and the protein content increases by $6.4 \%$. In addition, if the quality assurance period is extended by 11 times, and selenium-enriched eggs are used to make egg powder, the organic selenium content can be increased to 10 times that of ordinary eggs, and the protein content can reach 50\%[9]. Adding an appropriate amount of selenium to the daily feed of laying hens can increase the selenium content in the tissues and improve the reproductive performance, egg laying rate and muscle mass[15].

Generally speaking, related studies have observed the effects of dietary selenium supplements in a relatively short period of time, but there is little data on selenium diets that reach toxic doses, and most reports have focused on the effects of dietary supplementation of the same selenium source at different levels on egg selenium content. Therefore, in this study, in order to produce selenium-rich eggs, by designing various supplementary levels of selenium-rich bean sprout powder feed, and measuring its impact on the production performance and egg quality of laying hens, we found a appropriate method for producing selenium-rich eggs.

\section{MATERIALS AND METHODS}

\subsection{Selenium-enriched bean sprouts powder and basal diet fed used in the experiment}

The selenium-enriched bean sprouts powder used in the experiment was produced by Pyongyang University of Agriculture. Soybean: water is 1:3. Soybean seeds are soaked in water at $25^{\circ} \mathrm{C}$ for 6 hours for three times, and finally soaked at $20 \mathrm{mg} / \mathrm{L}$ sodium selenate solution. Incubate for 1 week by spraying $20 \mathrm{mg} / \mathrm{L}$ sodium selenite dilute solution at $22^{\circ} \mathrm{C}$ for 2 minutes each time and once every 4 hours. The grown bean sprouts were dried at a temperature below $70^{\circ} \mathrm{C}$, and then pulverized into powder to obtain a selenium-enriched bean sprouts powder, which was used in the test.

$1 \mathrm{~kg}$ of selenium-enriched bean sprouts powder contains $40 \mathrm{mg}$ selenium, in addition, carbohydrate $150 \mathrm{~g}$, protein $225 \mathrm{~g}$, fat $80 \mathrm{~g}$, fiber $75 \mathrm{~g}$, VitA $750 \mathrm{IU}$, VitC 400mg, VitE 40IU, VitB $12 \mathrm{mg}$, VitB $20.35 \mathrm{mg}$, VitPP 30mg, Mg 1000mg, Ca 1000mg, Fe 45mg, Zn 25mg, Cu 7.5mg, Mn 3.4mg, K 7.5g, P 3g, Na 350mg. The selenium content in the basal diet fed is $0.3 \mathrm{mg} / \mathrm{kg}$, which contains $16.00 \%$ crude protein, $3.20 \%$ crude fat, $3.5 \%$ calcium and $0.73 \%$ soluble phosphorus. The composition and nutritional level of the basal diet fed are shown in Table 1.

Table 1 Basal diet fed composition and nutritional level

\begin{tabular}{|l|l|l|l|}
\hline Ingredient & $\begin{array}{l}\text { Percent } \\
\text { age }\end{array}$ & Nutrient & Content \\
\hline
\end{tabular}




\begin{tabular}{|c|c|c|c|}
\hline $\begin{array}{l}\text { Corn/\% } \\
\text { Soybean } \\
\text { meal/\% } \\
\text { Mountain } \\
\text { flour/\% } \\
\text { Calcium } \\
\text { hydrophosphat } \\
\text { e/\% } \\
\text { Vitamin-mineral } \\
\text { premix/\% } \\
\text { Total/\% }\end{array}$ & $\begin{array}{l}66.00 \\
26.00 \\
4.00 \\
1.00 \\
3.00 \\
100\end{array}$ & $\begin{array}{l}\text { Metabolic } \\
\text { energy/(MJ } \\
\left.\cdot \mathrm{kg}^{-1}\right) \\
\text { Crude } \\
\text { protein/\% } \\
\text { Crude } \\
\text { fat/\% } \\
\text { Calcium/\% } \\
\text { Available } \\
\text { phosphoru } \\
\text { s /\% } \\
\text { Lysine/\% } \\
\text { Methionin } \\
\text { e+Cystine/ } \\
\% \\
\text { Methionin } \\
\text { e/\% }\end{array}$ & $\begin{array}{l}11.38 \\
16.00 \\
3.20 \\
3.50 \\
0.35 \\
0.70 \\
0.62 \\
0.35\end{array}$ \\
\hline
\end{tabular}

Note: 1. Premix provides per kilogram;VitA 8 000IU, VitD3 2 200IU, VitE 8IU, VitK3 1.5mg, VitB1 2.0mg, $\mathrm{VitB}_{2} 4.0 \mathrm{mg}$, VitB $2.0 \mathrm{mg}, \mathrm{VitB}_{12} 0.2 \mathrm{mg}$, Folic acid $1.0 \mathrm{mg}$, Choline $1500 \mathrm{mg}$, Cu $6.0 \mathrm{mg}$, Fe $80 \mathrm{mg}$, Mn $45 \mathrm{mg}$, Zn 55mg, I 0.3mg, Antioxidant, Salt. 2. The metabolic energy in the nutritional level is calculated value, and the rest are measured values.

Test animals: 500Hyline brown laying hens aged 32weeks were randomly divided into $5 \operatorname{groups}(\mathrm{A}, \mathrm{B}, \mathrm{C}$, $\mathrm{D}$, and $\mathrm{E}$ groups), each with 100chickens, divided into 4repeats, each repeat 25laying hens. The experimental chicken cages were of three-tier ladder type, 5laying hens in a cage.

\subsection{Experimental design}

The experiment was conducted on experimental animals at Pyongyang University of Agriculture from From September 2018 to July 2019. A single-factor experimental design was adopted and randomly divided into 5groups: Group A was the control group, and the control group was fed a basic diet with a selenium level of $0.30 \mathrm{mg} / \mathrm{kg}$ (the source of selenium in the basal diet fed was sodium selenite); group B selenium level $0.30 \mathrm{mg} / \mathrm{kg}$ (adding $7.5 \mathrm{~g} / \mathrm{kg}$ of seleniumenriched bean sprouts powder); group $\mathrm{C}$ selenium level is $0.6 \mathrm{mg} / \mathrm{kg}$ (adding selenium-enriched soybean sprouts powder $15 \mathrm{~g} / \mathrm{kg}$ ); D group selenium level is $0.9 \mathrm{mg} / \mathrm{kg}$ (adding selenium-enriched soybean sprouts powder $22.5 \mathrm{~g} / \mathrm{kg}$ ); group $\mathrm{E}$ selenium level is $1.2 \mathrm{mg} / \mathrm{kg}$ (adding selenium-enriched soybean sprouts powder $30 \mathrm{~g} / \mathrm{kg}$ ). After a 7 -day pre-test period, it was determined that there was no significant difference in the production performance of the test groups, and the test period was formally entered, with a total of 20weeks. During the test period, all the laying hens had free intake of food (with unlimited measurement) and free drinking, and the daily lighting time was fixed at $16 \mathrm{~h} / \mathrm{d}$. Keep the house clean and sanitary, and conduct regular disinfection and epidemic prevention.

\subsection{Measurement indicators and methods}

\subsubsection{Production performance}

The egg production of the day within laying test period will be recorded every day in each groups. There were regular weekly calculations of food supplies and remaining weight. During the experiment period the average egg laying rate, average egg weight and feed:egg mass ratio of each groups were counted.

Egg laying rate=total number of eggs laid during the statistical period/(number of chickens in stock $\times$ number of days in the statistical period $) \times 100(\%)$ (1)

Average daily feed intake=total weekly feed intake/number of chickens in stock (g/d)

Feed:egg mass ratio=total feed consumption/total egg weight( $\mathrm{kg}: \mathrm{kg})$

\subsubsection{Egg quality determination}

Collect egg samples on the 15th, 30th, 60th, 90th, 120th, and 140th after the start of the formal experiment, and randomly pick 5medium sized and normal colored eggs from each group for determination of egg quality. And the selenium content in the whole egg liquid. 
Use vernier calipers to measure the long and short diameters of eggs, calculate the egg shape index, and use a spiral micrometer (CLH12-211) to measure the thickness of the eggshell. The eggshell strength was measured with an eggshell strength tester (EFR-01). Egg shape index =egg long diameter/egg short diameter

2.3.3. Selenium content determination in egg sample

Egg sample treatment: Pour the egg content (egg yolk and egg white) into a large beaker without damage, stir it evenly with an egg beater, divide it into multiple $5 \mathrm{~mL}$ centrifuge tubes, record the number, and store it in a refrigerator at $-20{ }^{\circ} \mathrm{C}$. To determine the selenium content of whole eggs.

\subsubsection{Selenium content determination in meat sample}

Meat sample processing: On the last day of the test, three laying hens with an average weight were slaughtered. The breast muscle, liver, skin, and kidney tissues were extracted, and $5 \mathrm{~g}$ was taken, and the selenium content in each tissue was measured.

Atomic absorption spectroscopy(Varian Spectrum AA-220FS, CA) inductively coupled plasma mass spectrometer (Agilent 7500cx; Agilent, Tokyo, Japan) was used to determine the content of selenium[17].

\subsection{Data analysis}

All result data are statistically processed using SPSS

23.0 program, and the result is expressed as " $\overline{\mathrm{X}} \pm \mathrm{m}$ ".

When there is a significant difference, it is expressed as $P<0.05$.

\section{RESULTS}

\subsection{The effect of adding different levels of selenium- enriched bean sprouts powder on the performance of laying hens}

The effects of different levels of selenium-enriched bean sprouts powder on performance of laying hens were shown in Table 2.

Table 2 The effect of adding selenium-enriched bean sprouts powder on the performance of laying hens

\begin{tabular}{|c|c|c|c|c|c|}
\hline Item & Control A & Group B & $\begin{array}{c}\text { Group } \\
\text { C }\end{array}$ & $\begin{array}{c}\text { Group } \\
\text { D }\end{array}$ & $\begin{array}{c}\text { Gro } \\
\text { up } \\
\text { E }\end{array}$ \\
\hline Feed & $103.43^{\mathrm{b}} \pm 5$ & $106.39^{\mathrm{a}} \pm$ & 105.85 & 104.77 & 105. \\
\hline intake/( & 72 & 7.37 & ${ }^{\mathrm{a}} \pm 8.68$ & ${ }^{a} \pm 5.80$ & $32^{\mathrm{a}_{ \pm}}$ \\
\hline$\left.g \cdot d^{-1}\right)$ & $89.54^{\mathrm{b}} \pm 7.2$ & $90.77^{b} \pm 9$. & $92.15^{\mathrm{a}}$ & $90.08^{b}$ & 12.1 \\
\hline Egg laying & 5 & 04 & \pm 9.10 & \pm 10.83 & 4 \\
\hline rate $/ \%$ & $60.23^{\mathrm{a}} \pm 1.2$ & $61.52^{\mathrm{b}} \pm 2$ & $61.84^{b}$ & $61.15^{b}$ & 88.7 \\
\hline Egg & 1 & 46 & \pm 2.15 & \pm 1.61 & $1^{\mathrm{b}} \pm 1$ \\
\hline weight/g & $1.92^{\mathrm{b}} \pm 0.91$ & $1.91^{\mathrm{b}} \pm 0.9$ & $1.86^{\mathrm{a}} \pm$ & $1.90^{\mathrm{b}} \pm$ & 5.13 \\
\hline Feed:egg & & 2 & 1.110 & 0.97 & 60.9 \\
\hline mass & & & & & $1^{\mathrm{a}} \pm 0$ \\
\hline ratio/kg:k & & & & & .89 \\
\hline $\mathrm{g}$ & & & & & 1.95 \\
\hline & & & & & $\begin{array}{c}{ }^{c} \pm 1 \\
26\end{array}$ \\
\hline & & & & & \\
\hline & & & & & \\
\hline & & & & & \\
\hline
\end{tabular}

Note: Different lowercase letters on the shoulders of peer data indicate significant differences $(\mathrm{P}<0.05)$, and no letters or the same lowercase letters indicate insignificant differences $(P>0.05)$; the same in the table below.

It can be seen from Table 2 that when seleniumenriched bean sprouts powder is added to the basic diet of Hyline brown laying hens, according to the level of addition, there is a difference in daily feed intake, egg laying rate, egg weight and feed:egg mass ratio, which has a positive effect on egg production 
performance. In terms of daily feed intake, all test groups have significant differences compared to control group A $(P<0.05)$, but both test groups are slightly higher but the difference is not significant $(P>0.05)$. In terms of egg laying rate, the highest egg laying rate of $C$ group was $92.15 \%$, so the difference from the control group (89.54\%) was significant $(P<0.05)$, but the difference between the other test groups and the control group was not significant $(P>0.05)$. In terms of egg weight, there was a significant difference between the test group and the control group $(P<0.05)$, but there was no significant difference between the test groups $(P>0.05)$. In the feed:egg mass ratio, the $\mathrm{C}$ group was at least $1.86 \mathrm{~kg} / \mathrm{kg}$, and the E group was the highest at $1.95 \mathrm{~kg} / \mathrm{kg}(P<0.05)$. There was no significant difference between the other test groups and the control group $(P>0.05)$.

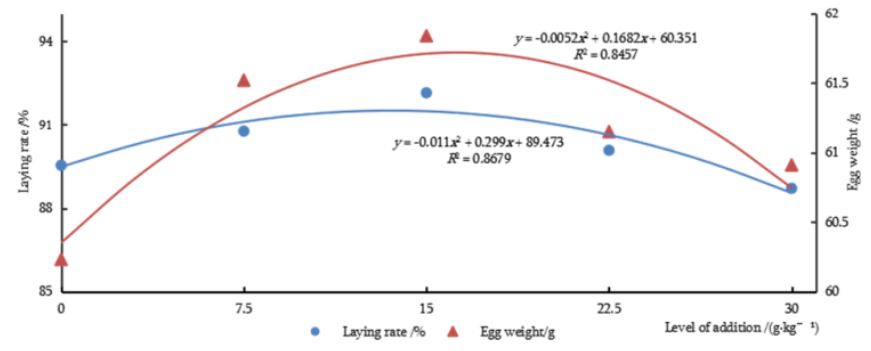

Fig.1 The effect of adding selenium-enriched bean sprouts powder on egg laying rate and egg weight

As shown in Fig. 1, if the selenium-enriched bean sprouts powder is fed to laying hens, the egg laying rate follows the quadratic function relationship $y=-$ $0.011 x^{2}+0.299 x+89.473\left(R^{2}=0.8679\right)$. In order to increase the egg laying rate, the best addition amount is $13.59 \mathrm{~g} / \mathrm{kg}$ in the basal diet fed. If the seleniumenriched soybean sprout seedling vegetable powder is added to the ingredients, the relationship with the egg weight is in a quadratic function, $y=-$ $0.0052 x^{2}+0.1682 x+60.351\left(R^{2}=0.8457\right)$, and the optimal addition amount is $16.17 \mathrm{~g} / \mathrm{kg}$. It was confirmed that adding $14^{\sim} 16 \mathrm{~g} / \mathrm{kg}$ of selenium-enriched bean sprouts powder in the feed for laying hens had the greatest impact on egg production.

\subsection{The effect of selenium-enriched bean sprouts powder on egg quality}

The trace element selenium enters the body and has a certain effect on the thickness and strength of the eggshell.

Table 3. Effect of adding different content of selenium-enriched bean sprouts powder on egg quality

\begin{tabular}{|c|c|c|c|c|c|c|}
\hline Item & Trial period/d & Control A & Group B & Group C & Group D & Group E \\
\hline \multirow[t]{6}{*}{ Egg weight/g } & 15 & $56.83 \pm 2.04$ & $57.29 \pm 2.37$ & $57.87 \pm 2.36$ & $57.16 \pm 3.44$ & $57.35 \pm 2.21$ \\
\hline & 30 & $58.47^{b} \pm 2.38$ & $59.86^{\mathrm{b}} \pm 2.88$ & $60.48^{\mathrm{a}} \pm 2.27$ & $60.84^{\mathrm{a}} \pm 3.23$ & $60.20^{\mathrm{a}} \pm 2.15$ \\
\hline & 60 & $60.83^{\mathrm{b}} \pm 2.83$ & $61.43^{\mathrm{b}} \pm 2.15$ & $61.58^{b} \pm 2.89$ & $64.41^{\mathrm{a}} \pm 3.76$ & $60.81^{b} \pm 3.24$ \\
\hline & 90 & $61.21 \pm 3.64$ & $62.83 \pm 3.36$ & $62.87 \pm 2.87$ & $61.78 \pm 3.75$ & $61.89 \pm 4.62$ \\
\hline & 120 & $62.13 \pm 3.46$ & $63.74 \pm 4.58$ & $63.82 \pm 3.58$ & $62.25 \pm 4.19$ & $62.21 \pm 4.44$ \\
\hline & 140 & $62.41^{\mathrm{b}} \pm 4.87$ & $63.96^{\mathrm{b}} \pm 3.61$ & $64.43^{\mathrm{a}} \pm 4.58$ & $63.48^{\mathrm{b}} \pm 4.69$ & $63.01^{\mathrm{b}} \pm 4.85$ \\
\hline Egg Shape & 15 & $1.31 \pm 0.08$ & $1.31 \pm 0.06$ & $1.31 \pm 0.07$ & $1.32 \pm 0.08$ & $1.31 \pm 0.08$ \\
\hline \multirow[t]{5}{*}{ index } & 30 & $1.33 \pm 0.09$ & $1.32 \pm 0.08$ & $1.32 \pm 0.09$ & $1.31 \pm 0.08$ & $1.30 \pm 0.11$ \\
\hline & 60 & $1.36^{\mathrm{a}} \pm 0.12$ & $1.31^{\mathrm{a}} \pm 0.11$ & $1.28^{b_{ \pm}} 0.08$ & $1.29^{\mathrm{b}} \pm 0.10$ & $1.32^{\mathrm{a}} \pm 0.01$ \\
\hline & 90 & $1.35^{\mathrm{a}} \pm 0.12$ & $1.32^{\mathrm{a}} \pm 0.11$ & $1.29^{b} \pm 0.10$ & $1.29^{b} \pm 0.12$ & $1.30^{\mathrm{b}} \pm 0.12$ \\
\hline & 120 & $1.34^{\mathrm{a}} \pm 0.13$ & $1.33^{\mathrm{a}} \pm 0.11$ & $1.30^{\mathrm{b}} \pm 0.12$ & $1.32^{\mathrm{a}} \pm 0.12$ & $1.30^{\mathrm{a}} \pm 0.12$ \\
\hline & 140 & $1.36^{\mathrm{a}} \pm 0.15$ & $1.30^{\mathrm{b}} \pm 0.13$ & $1.31^{\mathrm{b}} \pm 0.12$ & $1.32^{\mathrm{a}} \pm 0.12$ & $1.33^{\mathrm{a}} \pm 0.15$ \\
\hline Eggshell & 15 & $30.2 \pm 0.35$ & $32.3 \pm 0.38$ & $32.6 \pm 0.30$ & $32.9 \pm 0.42$ & $33.4 \pm 0.40$ \\
\hline stiffness/ & 30 & $31.5 \pm 0.43$ & $32.9 \pm 0.46$ & $33.5 \pm 0.41$ & $34.6 \pm 0.57$ & $34.7 \pm 0.54$ \\
\hline
\end{tabular}




\begin{tabular}{|c|c|c|c|c|c|c|}
\hline \multirow[t]{4}{*}{$\left(\mathrm{N} \cdot \mathrm{cm}^{-2}\right)$} & 60 & $30.2^{b} \pm 0.41$ & $34.3^{\mathrm{a}} \pm 0.41$ & $35.6^{\mathrm{a}} \pm 0.45$ & $35.2^{\mathrm{a}} \pm 0.64$ & $36.2^{\mathrm{a}} \pm 0.66$ \\
\hline & 90 & $29.2^{\mathrm{b}} \pm 0.47$ & $33.2^{\mathrm{a}} \pm 0.52$ & $35.8^{\mathrm{a}} \pm 0.49$ & $36.6^{\mathrm{a}} \pm 0.72$ & $37.2^{\mathrm{a}} \pm 0.65$ \\
\hline & 120 & $29.6^{b} \pm 0.63$ & $32.2^{b} \pm 0.72$ & $36.2^{a} \pm 0.69$ & $35.9^{a} \pm 0.68$ & $37.3^{a} \pm 0.67$ \\
\hline & 140 & $28.4^{b} \pm 0.57$ & $31.1^{b} \pm 0.76$ & $36.1^{\mathrm{a}} \pm 0.53$ & $35.5^{\mathrm{a}} \pm 0.75$ & $36.8^{\mathrm{a}} \pm 0.72$ \\
\hline Eggshell & 15 & $0.31 \pm 0.02$ & $0.31 \pm 0.03$ & $0.31 \pm 0.02$ & $0.31 \pm 0.02$ & $0.32 \pm 0.02$ \\
\hline thickness/m & 30 & $0.30 \pm 0.03$ & $0.30 \pm 0.01$ & $0.31 \pm 0.02$ & $0.33 \pm 0.03$ & $0.33 \pm 0.03$ \\
\hline \multirow[t]{4}{*}{$\mathrm{m}$} & 60 & $0.30^{\mathrm{b}} \pm 0.02$ & $0.31^{\mathrm{b}} \pm 0.02$ & $0.32^{b} \pm 0.02$ & $0.34^{\mathrm{a}} \pm 0.03$ & $0.34^{\mathrm{a}} \pm 0.03$ \\
\hline & 90 & $0.31 \pm 0.03$ & $0.32 \pm 0.02$ & $0.32 \pm 0.03$ & $0.32 \pm 0.03$ & $0.33 \pm 0.03$ \\
\hline & 120 & $0.29^{b} \pm 0.02$ & $0.31^{b} \pm 0.03$ & $0.33^{\mathrm{a}} \pm 0.03$ & $0.33^{\mathrm{a}} \pm 0.03$ & $0.32^{b} \pm 0.02$ \\
\hline & 140 & $0.29 \pm 0.02$ & $0.30 \pm 0.03$ & $0.31 \pm 0.03$ & $0.32 \pm 0.03$ & $0.32 \pm 0.02$ \\
\hline
\end{tabular}

It can be seen from Table 3 that the egg weights of groups $\mathrm{C}$ and $\mathrm{D}$ were significantly higher than those of the control group at $30 \mathrm{~d}, 60 \mathrm{~d}$, and $140 \mathrm{~d}$ during the test period $(P<0.05)$. During the test period, the egg shape index of group $C$ was significantly lower than that of control group, group B was 140d, group D was 60d, 90d, and group E was 90d lower than control $\operatorname{group}(P<0.05)$. In terms of eggshell strength, 60 days after the start of the test, the test groups $\mathrm{C}, \mathrm{D}$, and $\mathrm{E}$ have significant differences compared with the control group $(P<0.05)$, while the difference in group $\mathrm{B}$ is only significant at 60 and 90days after the start of the test there is no significant difference from the $\operatorname{group}(P>0.05)$. There was no significant difference from the control group during the rest of the period. Similarly, in the thickness of the eggshell, the test groups $\mathrm{C}, \mathrm{D}$, and $\mathrm{E}$ were higher than the control group $(P<0.05)$, while the $\mathrm{B}$ group and the control group had no significant difference $(P>0.05)$.

\subsection{The effect of different levels of selenium-enriched bean sprouts powder on the selenium content in eggs}

The analysis results of the effects of different levels of selenium-enriched bean sprouts powder on the selenium content of eggs are shown in Table 4.

Table 4 Selenium content in eggs of different groups $\quad /\left(\mathrm{mg} / \mathrm{kg}^{-1}\right)$

Trial Control Grou Group Grou Group E

\begin{tabular}{|c|c|c|c|c|c|}
\hline $\begin{array}{l}\text { period } \\
\text { /d }\end{array}$ & A & p B & $\mathrm{C}$ & $\mathrm{p} \mathrm{D}$ & \\
\hline 15 & $0.28 \div 0$. & $0.46^{\mathrm{b}} \pm$ & $0.58 \mathrm{a} \pm 0$. & $0.60^{4} \pm$ & $0.58 \pm 0.06$ \\
\hline 30 & 02 & 0.03 & 05 & 0.05 & $0.46^{\mathrm{b}} \pm 0.0$ \\
\hline 60 & $0.30 ₫ 0$. & $0.50^{b_{ \pm}}$ & $0.54^{\mathrm{b}} \pm 0$. & $0.62^{a} \pm$ & 8 \\
\hline 90 & 02 & 0.02 & 08 & 0.07 & $0.52^{\mathrm{a}} \pm 0.07$ \\
\hline 120 & $0.30^{b} \pm 0$. & $0.52^{\mathrm{a}} \pm$ & $0.58 \mathrm{a} \pm 0$. & $0.59^{a} \pm$ & $0.46^{\mathrm{b}} \pm 0.1$ \\
\hline \multirow[t]{7}{*}{140} & 03 & 0.05 & 07 & 0.07 & 0 \\
\hline & $0.29 \_ \pm 0 .$ & $0.49^{\mathrm{b}} \pm$ & $0.56^{\mathrm{b}} \pm 0$. & $0.58^{a} \pm$ & $0.53^{b} \pm 0.1$ \\
\hline & 04 & 0.05 & 08 & 0.08 & 0 \\
\hline & $0.28 ₫ 0$. & $0.46^{\mathrm{b}_{ \pm}}$ & $0.60^{a} \pm 0$. & $0.60^{a} \pm$ & $0.49^{b} \pm 0.1$ \\
\hline & 04 & 0.07 & 08 & 0.06 & 2 \\
\hline & $0.29 \pm 0$. & $0.44_{ \pm}^{b_{ \pm}}$ & $0.58 \mathrm{a} \pm 0$. & $0.61^{a} \pm$ & \\
\hline & 04 & 0.06 & 09 & 0.08 & \\
\hline \multirow{3}{*}{$\begin{array}{l}\text { 平均 } \\
\text { 对 比 } \\
1 \%\end{array}$} & \multirow{3}{*}{$\begin{array}{l}0.29 \\
100.0\end{array}$} & 0.478 & \multirow{3}{*}{$\begin{array}{l}0.573 \\
197.7\end{array}$} & 0.6 & \multirow{3}{*}{$\begin{array}{l}0.507 \\
174.71\end{array}$} \\
\hline & & 164.9 & & 206.9 & \\
\hline & & 4 & & 0 & \\
\hline
\end{tabular}

It can be seen from Table 4 that the addition of selenium-enriched bean sprouts powder to the basic diet can significantly increase the selenium content in whole eggs $(P<0.05)$. With the increase in the amount of addition, the selenium content in the eggs increased significantly, but the selenium content in the eggs of group $\mathrm{E}$ was significantly lower than that of group $\mathrm{D}(P<0.05)$. Compared with the control group $\mathrm{A}$, the selenium content in the eggs of the test groups $\mathrm{B}, \mathrm{C}, \mathrm{D}$, and $\mathrm{E}$ respectively increased by $164.94 \%, 197.7 \%$, 206.90\%, and $174.71 \%$. 


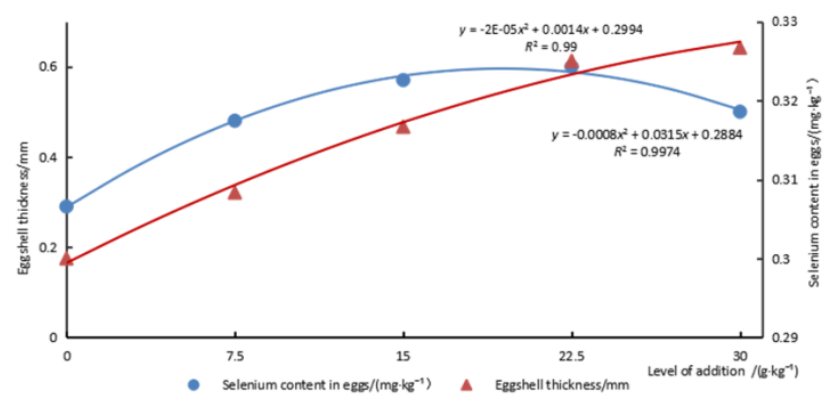

Fig.2 The effect of adding selenium-enriched bean sprouts powder on eggshell thickness and selenium content in eggs

As shown in Figure 2, if the selenium-enriched bean sprouts powder is fed to laying hens, the selenium content in the eggs is in a quadratic function relationship $y=-0.00002 x^{2}+0.0014 x+0.2994 \quad\left(R^{2}=0.99\right)$. In order to increase the selenium content in eggs, the best addition amount is $19.69 \mathrm{~g} / \mathrm{kg}$ in the basal diet fed. If selenium-enriched bean sprouts powder is added to the basal diet fed, the addition amount and eggshell thickness are quadratic function $y=-$ $0.0008 x^{2}+0.0315 x+0.2884\left(R^{2}=0.99\right)$. The results show that it is effective to add $19.69 \mathrm{~g} / \mathrm{kg}$ selenium-enriched bean sprouts powder to the feed of laying hens. Finally, add $15^{\sim} 20 \mathrm{~g} / \mathrm{kg}$ of selenium-enriched bean sprouts powder that is most suitable for improving egg production performance and selenium content in eggs (the selenium content of basic basal diet fed is $0.3 \mathrm{mg} / \mathrm{kg}+$ organic selenium $0.6^{\sim} 0.8 \mathrm{mg} / \mathrm{kg}$ ).

\subsection{The effect of adding different selenium-enriched bean sprouts powder on the selenium content in tissues}

At the end of the experiment, 3 laying hens of each group were slaughtered, breast muscle, liver, skin and kidney tissues were cut, and the selenium content in each tissue was measured by atomic absorption spectroscopy. The results are as follows.

Table 5. Selenium content in breast muscle, liver, skin and kidney tissues $/\left(\mathrm{mg} \cdot \mathrm{kg}^{-1}\right)$

\begin{tabular}{|c|c|c|c|c|c|}
\hline Item & $\begin{array}{l}\text { Control } \\
\text { A }\end{array}$ & $\begin{array}{l}\text { Group } \\
\text { B }\end{array}$ & $\begin{array}{l}\text { Group } \\
\text { C }\end{array}$ & $\begin{array}{l}\text { Group } \\
\text { D }\end{array}$ & $\begin{array}{l}\text { Group } \\
\text { E }\end{array}$ \\
\hline Breast & $0.23^{\mathrm{d}_{ \pm}}$ & $0.42^{c_{ \pm}}$ & $0.68^{b_{ \pm}}$ & $0.79^{\mathrm{a}} \pm$ & $0.84^{\mathrm{a} \pm}$ \\
\hline muscle & 0.02 & 0.03 & 0.03 & 0.04 & 0.05 \\
\hline Liver & $1.44^{\mathrm{d} \pm}$ & $1.69^{\mathrm{c}} \pm$ & $1.78^{\mathrm{c}} \pm$ & $1.85^{\mathrm{b}} \pm$ & $1.92^{\mathrm{a} \pm}$ \\
\hline Skin & 0.17 & 0.19 & 0.20 & 0.22 & 0.21 \\
\hline \multirow[t]{4}{*}{ Kidney } & $0.17^{\mathrm{c}_{ \pm}}$ & $0.33^{\mathrm{a}} \pm$ & $0.46^{\mathrm{a}} \pm$ & $0.49^{\mathrm{ab}_{ \pm}}$ & $0.53^{\mathrm{ab}}$ \\
\hline & 0.01 & 0.03 & 0.03 & 0.04 & \pm 0.04 \\
\hline & $0.65^{\mathrm{d} \pm}$ & $0.74^{\mathrm{d}_{ \pm}}$ & $0.93^{\mathrm{c}} \pm$ & $1.12^{\mathrm{b}} \pm$ & $1.28^{\mathrm{a}} \pm$ \\
\hline & 0.03 & 0.05 & 0.06 & 0.12 & 0.14 \\
\hline
\end{tabular}

As shown in Table 5, adding selenium-enriched bean sprouts powder will affect the selenium content in various tissues of laying hens. With the increase in the amount of selenium-enriched bean sprouts powder, the selenium content in breast muscle, liver, skin and kidney increased, but no significant difference was observed between $\mathrm{E}$ and $\mathrm{D}$ groups $(P>0.05)$. Compared with the control group, the content of selenium in the chest muscles, liver, skin and kidney of the $\mathrm{B}, \mathrm{C}, \mathrm{D}$, and $\mathrm{E}$ groups increased significantly $(P<0.05)$. During the whole test period, no chickens died in each group, and no symptoms of acute poisoning (such as blindness, abdominal pain, muscle paralysis, dyspnea) or chronic poisoning symptoms (such as depilation, toenail discoloration and brittle, joint swelling, liver damage, etc.) were found.

\section{DISCUSSION}

\subsection{The content of selenium in feed will affect the productivity of eggs.}

There are many factors that affect the performance of laying hens, including individual differences, environment, dietary energy level, etc. Egg laying rate, average egg weight, eggshell weight, and eggshell strength are important indicators to evaluate the performance of laying hens.

V. Tufarelli et al.,(2016)[14] found that after adding exogenous selenium to the diet of 40 -week-old 
brown-shell laying hens, there was no significant difference in daily feed intake, egg weight, and egg laying rate. However, Zoran Pavlović et al.,(2010)[17] studied the effect of feeding selenium (inorganic selenium $0.4 \mathrm{mg} / \mathrm{kg}$ or yeast selenium $0.8 \mathrm{mg} / \mathrm{kg}$ ) on the productivity of egg-laying chickens. As a result, egg weight, broken egg ratio, and feed intake by 8 weeks of test there was no significant difference $(P<0.05)$, but after the 9 th week of the test, it was revealed that the yeast selenium group had higher egg production than the sodium selenite $(P<0.01)$.

In this experiment, adding selenium-enriched bean sprouts powder to the basal diet fed of Hyline brown laying hens, there was a significant difference in daily feed intake compared with the control group, especially when were added $7.5 \mathrm{~g} / \mathrm{kg}$ seleniumenriched bean sprouts powder, B group the average daily feed intake was $2.96 \mathrm{~g} / \mathrm{d}$ higher than control group $(P<0.05)$, and there was no significant difference between the test groups $(P>0.05)$. In terms of egg laying rate, the test $C$ group was $102.9 \%$ higher than control group, the difference was significant $(P<0.05)$, while the other test groups had no significant difference compared with control group. On the contrary, the E group was slightly lower than the control group ( $P>0.05)$. In terms of egg weight, group $\mathrm{B}$ and group $\mathrm{C}$ were $1.29 \mathrm{~g}$ and $1.61 \mathrm{~g}$ higher than control group $(P<0.05)$, but there was no significant difference between group $\mathrm{D}$ and group $\mathrm{E}$ and the control group ( $P$ 0.05). Results The feed:egg mass ratio was 1.86 in group $C$, which was the smallest compared with 1.92 in the control group, while it was 1.95 in group $\mathrm{E}$, which was the highest $(P<0.05)$. There was no significant difference between the other test groups and the control group.

The reason why the above research results are different from the previous literature data seems to be due to the different types of eggs and poultry in the experiment, the different production stages, and the breeding environment, as well as the differences in the selenium source and the added level. In this study, the addition of different levels of selenium-enriched bean sprouts powder has a certain impact on the egg laying rate of laying hens, especially $15^{\sim} 22.5 \mathrm{~g} / \mathrm{kg}$ added to the basal diet fed(the selenium content in the feed is $0.6^{\sim} 0.9 \mathrm{mg} / \mathrm{kg}$ ), it has a positive impact on the production performance of laying hens, but under low or high level conditions, it will not significantly affect the egg laying rate.

\subsection{The effect of selenium level in feed on egg quality}

Egg weight, egg shape index, eggshell thickness, eggshell strength, etc. are important indicators for evaluating egg quality. Egg weight is an important indicator for evaluating egg grade and an important trait for breed selection. The egg shape index is a parameter describing the length and width of an egg, and is the most intuitive indicator when observing the shape of an egg. The strength of the eggshell refers to the degree of pressure resistance of the eggshell, which is related to the rate of shell breakage. The thickness of the eggshell is positively related to the strength of the eggshell, and is closely related to the specific gravity of the egg. However, according to research data such as Elzbieta Lipiec.(2010)[18] compared with the control group without selenium, adding different levels of selenium to the feed has little effect on the egg egg laying rate of brown layers, but has a great effect on the thickness of the eggshell. The test group added $0.4 \mathrm{mg} / \mathrm{kg}$ inorganic selenium and $0.4 \mathrm{mg} / \mathrm{kg}$ yeast selenium had higher egg weight (3.61\%, 2.95\%) and egg shell weight (4.26\%, 5.38\%) than the control group with $0.11 \mathrm{mg} / \mathrm{kg}$ inorganic selenium. $P<0.05)$. M Jlali et al,.(2013)[19] revealed that adding vitamin $\mathrm{E}$ and selenium to the feed of egg-laying quail can increase the strength of the egg yolk membrane, prolong the storage period, and increase the nutritional level of the egg yolk. SE Scheideler(2010)[6] and other experimental studies have found that adding yeast selenium to feed can significantly increase eggshell weight, eggshell strength and egg shell thickness, but has no significant effect on egg shape index. Studies such as M Youssefi(2014)[20] have shown that if a certain 
concentration of yeast-enriched selenium is added to the diet fed, it can improve the strength and color of the eggshell. Adding yeast selenium to chicken feed will significantly increase the selenium content in eggs $(P<0.05)$, and the egg selenium content will increase significantly with the addition of yeast selenium in the feed $[9,16]$.

Adding selenium to the diet can increase the selenium concentration in eggs compared with the control group. Of course, this is related to organic selenium or inorganic selenium. When yeast selenium or inorganic selenium is added to the feed of laying hens, the selenium content in the eggs will double. Compared with inorganic selenium, yeast selenium can increase the selenium deposition rate in eggs by $47 \%[21]$. When supplementing the same dose of selenium, yeast selenium will increase more because most of the selenium in yeast selenium is composed of selenomethionine similar to methionine. When the dose exceeds ten times the required dose, selenium is toxic to poultry. Yeast selenium preparations are less toxic than inorganic forms of selenium, such as sodium selenite[22]. When $0.8,2.4,4.0,6.4,9.0 \mathrm{mg} / \mathrm{kg}$ sodium selenite is added to the feed of laying hens, due to the toxicity of sodium selenite, after the 9th week, the egg production efficiency is reduced when the level is above $0.8 \mathrm{mg} / \mathrm{kg}[9]$.

In this study, the addition of selenium-enriched bean sprouts powder to the feed had a significant effect on egg weight, egg laying rate, eggshell strength and eggshell thickness $(P<0.05)$. During the 140 days test period, with the increase in the amount of seleniumenriched bean sprouts powder in the feed, the quality of the eggs was improved, and the selenium content in the eggs was significantly increased, which is consistent with the results of the previous literature. From 15 to 140days, the selenium content in eggs of all test groups containing selenium-enriched bean sprouts powder was significantly higher than that in the control group (the selenium level was $0.3 \mathrm{mg} / \mathrm{kg}$ inorganic selenium). On the 15th, 30th, 120th and 140th of the test, the selenium content in the eggs of the group $\mathrm{C}$ and $\mathrm{D}$ was significantly higher than group B (the selenium content was $0.3 \mathrm{mg} / \mathrm{kg}$, and the selenium-enriched bean sprouts powder was added $7.5 \mathrm{~g} / \mathrm{kg}$ to the basal diet fed). The test $\mathrm{E}$ group (selenium content is $1.2 \mathrm{mg} / \mathrm{kg}$, the basic ingredient is added with selenium-enriched bean sprouts powder $30 \mathrm{~g} / \mathrm{kg}$ ), which is fed the highest selenium level feed for a long time, has a tendency to feed lower selenium feed $\mathrm{C}$ or D group. This indicates that feeding a layer of hens with a high selenium level of $1.2 \mathrm{mg} / \mathrm{kg}$ will cause the body to become weak for a long time, thereby reducing its ability to transfer to eggs, will not continue to improve. It has not been determined yet and more research and review is needed.

On the 15th day after the start of the test, there was no significant difference in the selenium content in the eggs of the test groups $\mathrm{C}, \mathrm{D}$, and $\mathrm{E}$ (the selenium content was $0.6^{\sim} 1.2 \mathrm{mg} / \mathrm{kg}$, added $15^{\sim} 30 \mathrm{~g} / \mathrm{kg}$ of selenium-enriched bean sprouts powder $)(\mathrm{P}>0.05)$. However, from the 60th day, the selenium content in the eggs of the $\mathrm{E}$ group continued to decrease compared with the test $\mathrm{C}$ and $\mathrm{D}$ groups $(P<0.05)$.

According to the test results, it was found that after adding selenium-enriched bean sprouts powder, selenium chicken eggs can be obtained from the 15th day. When the selenium-enriched bean sprouts powder was added to the feed for more than 100days, the average selenium content of the eggs in the test group $\mathrm{B}$ (the selenium level was $0.6 \mathrm{mg} / \mathrm{kg}$ ) was $0.478 \mu \mathrm{g} / \mathrm{g}$, and $\mathrm{E}$ group(the high selenium content was $1.5 \mathrm{mg} / \mathrm{kg}$ ) to reach $0.507 \mu \mathrm{g} / \mathrm{g}$.

NRC states that adults should consume $50^{\sim} 250 \mu \mathrm{g}$ of

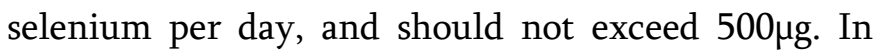
some countries, the selenium content in the soil is usually only 0.5 to $2.0 \mathrm{mg} / \mathrm{kg}$. Some areas are far apart, with an average of $0.2 \mathrm{mg} / \mathrm{kg}[11]$. The human body usually gets selenium from plants and animals. In selenium deficient areas, selenium does not meet the demand standard. For people in these areas, reasonable selenium supplementation is very necessary[23]. 
According to calculations, when the egg weight is $60 \mathrm{~g}$, the selenium content in an egg in the control group $\mathrm{A}$ is $17.4 \mu \mathrm{g}$, and the selenium deposits in an egg in the test $\mathrm{D}$ and $\mathrm{E}$ groups are $36 \mu \mathrm{g}$ and $30.4 \mu \mathrm{g}$, respectively. If adults consume $20 \sim 30 \mu \mathrm{g}$ of selenium from other foods a day, and eat 1 selenium-enriched egg a day, they can reach the minimum selenium level recommended by the NRC of $50^{\sim} 250 \mu \mathrm{g}$. If you eat 2 5eggs every day, you can reach the recommended dosage range. If you do not exceed the maximum limit of $500 \mu \mathrm{g}$, you will not be poisoned.

Therefore, under the condition that the selenium level in the feed for laying hens is $0.6^{\sim} 1.5 \mathrm{mg} / \mathrm{kg}$ (selenium-enriched bean sprouts powder $7.5^{\sim} 30 \mathrm{~g} / \mathrm{kg}$, sodium selenite $0.3 \mathrm{mg} / \mathrm{kg}$ ), the selenium-enriched eggs produced can be Meet the selenium demand of ordinary people and achieve the purpose of supplementing selenium.

\subsection{Influence on the selenium content of tissues}

When organic selenium is provided, the selenium content in the tissue is higher than that when inorganic selenium is provided. In other words, feeding yeast selenium to laying hens is expected to increase the selenium content in tissues. In fact, compared with inorganic selenium, the addition of yeast selenium will increase the selenium content in the breast muscle of hens. It was observed that the concentration of selenium in the breast muscle of the hens fed with yeast selenium was increased compared to the hens fed with sodium selenite. The muscle tissue of chickens fed with yeast selenium is the most important part of selenium deposits[16].

The selenomethionine absorbed from the digestive tract non-specifically binds to the structural proteins of muscles, stomach, heart and other organs, and these structural proteins cannot be used for protein synthesis immediately[24].

Muscle tissue is the most important part of the accumulation of selenium in the form of selenomethionine. Selenomethionine accumulated in muscle protein is very important in improving the selenium transport of protein and egg yolk in laying hens and improving the immunity of chickens and overall health[25]. Inorganic selenium or yeast selenium compounds can increase the concentration of selenium in the liver of laying hens, but it is reported that using organic selenium is more effective than inorganic selenium[26].

In this experiment, as the amount of selenium added increased, the selenium concentration in the liver also increased, and a statistically significant difference was found. However, if the selenium concentration is too high, there is no significant difference between the selenium content and the medium-level selenium feeding in the liver. The concentration of selenium in the skin is the same as that in the liver. The content of selenium in the kidneys of laying hens fed with selenium-enriched bean sprouts powder was higher than that of the control group, and the difference was statistically significant. It can be assumed that adding sodium selenite to the basal diet fed will cause more selenium to be excreted through the kidneys. When comparing laying hens fed with sodium selenite and laying hens fed with selenium-enriched bean sprouts, the concentration of selenium in the kidney was slightly lower. When supplied to feed in the form of inorganic selenium, excess inorganic selenium that exceeds the maintenance or production requirements will be excreted through the kidneys, but organic selenium forms such as yeast selenium will be absorbed by the capillaries of the kidneys and renewed through the blood, enter the metabolism. Shows that it is not excreted in urine.The content of selenium in the kidney reflects the content of selenium accumulated in the kidney and the content of selenium excreted by the organism body through urine. Sodium selenite absorbed from the small intestine non-specifically binds to plasma albumin within a few minutes. After sodium selenite is converted into organic selenium and methylated, it circulates several times in the body, and only the remaining inorganic selenium is excreted through urine. 
It can be seen from the test data that feeding a diet enriched in selenium for a relatively long period of time will not pose a potential risk to the health of the body. During the egg production test, none of the test groups had any abnormal symptoms or death, and it was found that under the conditions of this study, the level of selenium-enriched bean sprouts powder (selenium level $1.5 \mathrm{mg} / \mathrm{kg}$ ) did not cause adverse symptoms, such as egg poisoning, laying chickens . This further explains the safety of selenium supplements from the perspective of animal health. According to NRC data, the maximum tolerable level of selenium. For humans, if the selenium in food is less than $0.05 \mathrm{mg} / \mathrm{kg}$, it will cause selenium deficiency in the human body. If it is more than $3 \sim 5 \mathrm{mg} / \mathrm{kg}$, it will cause poisoning. The safest range is Between $0.1^{\sim} 0.36 \mathrm{mg} / \mathrm{kg}[8]$. In addition, according to many literature data, selenium-enriched bean sprouts powder is a kind of organic selenium. Because of its low toxicity, it is a good way to supplement selenium.

\section{CONCLUSION}

During the $140 \mathrm{~d}$ period of the egg production test, adding selenium-enriched bean sprouts powder (selenium content $40 \mathrm{mg} / \mathrm{kg}$ ) $7.5^{\sim} 30 \mathrm{~g} / \mathrm{kg}$ to the basal diet fed (inorganic selenium content $0.3 \mathrm{mg} / \mathrm{kg}$ ) of laying hens can significantly improve egg production performance and egg quality. The experimental group with $15^{\sim} 22.5 \mathrm{~g} / \mathrm{kg}$ of selenium-enriched bean sprouts powder added to the basal diet fed, compared with the control group, the egg laying rate, daily feed intake, eggshell strength, and eggshell thickness increased by $100.6^{\sim} 102.9 \%$ and $101.3^{\sim} 102.3 \%$, 117.1 117.6\%, 105.6 108.3\%. The content of selenium in eggs increased by $197.7^{\sim 206.9 \%}$ compared with the addition of $0.3 \mathrm{mg} / \mathrm{kg}$ of inorganic selenium (sodium selenite), and it increased significantly from the 15th day of the laying test. If the selenium-enriched bean sprouts powder is added to the level of $30 \mathrm{~g} / \mathrm{kg}$ (the selenium level in the basal diet fed is $1.5 \mathrm{mg} / \mathrm{kg}$ ), it will reduce the egg laying rate and the selenium content in the eggs. The selenium level in the feed is $0.6^{\sim} 0.9 \mathrm{mg} / \mathrm{kg}$ (selenium-enriched

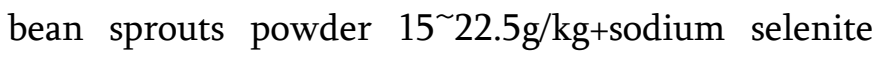
$0.3 \mathrm{mg} / \mathrm{kg}$ ) to produce a kind of selenium-enriched eggs, which will not affect the egg quality.

Such data will provide a theoretical basis for producing enriched in selenium eggs, an essential element for human health, using organic selenium.

\section{REFERENCES}

[1]. Surai P F , Kochish I I, Fisinin V I , et al. Selenium in Poultry Nutrition: from Sodium Selenite to Organic Selenium Sources[J]. The Journal of Poultry Science, 2018, 55(2): 79-93

[2]. Baylan M, Ca Nogullari S, Ayasan T, et al. Effects of Dietary Selenium Source, Storage Time, and Temperature on the Quality of Quail Eggs[J]. Biological Trace Element Research, 2011, 143(2):957-964.

[3]. Shinde P L, Dass R S, Garg A K. Effect of vitamin $\mathrm{E}$ and selenium supplementation on haematology, blood chemistry and thyroid hormones in male buffalo (Bubalus bubalis) calves[J]. Journal of Animal \& Feed Sciences, 2009, 18(2):241-256.

[4]. Speight S M, Estienne M J, Harper A F, et al. Effects of organic selenium supplementation on growth performance, carcass measurements, tissue selenium concentrations, characteristics of reproductive organs, and testis gene expression profiles in boars[J]. Journal of Animal Science, 2012, 90(2):533.

[5]. P.F. Surai a b c d e, Vif F. Selenium in poultry breeder nutrition: An update - ScienceDirect[J]. Animal Feed Science and Technology, 2014, 191:1-15.

[6]. Scheideler S E, Weber P, D Monsalve. Supplemental vitamin $\mathrm{E}$ and selenium effects on egg production, egg quality, and egg deposition of -tocopherol and selenium[J]. The Journal of Applied Poultry Research, 2010, 19(4):354-360. 
[7]. Ma Y L, MD Lindemann, Pierce J L, et al. Effect of inorganic or organic selenium supplementation on reproductive performance and tissue trace mineral concentrations in gravid first-parity gilts, fetuses, and nursing piglets.[J]. Journal of Animal Science, 2014, 92(12):55405550.

[8]. Kiełczykowska M, Kocot J, Kurzepa J, et al. Could Selenium Administration Alleviate the Disturbances of Blood Parameters Caused by Lithium Administration in Rats?[J]. Biological trace element research, 2014, 158(3):359-364.

[9]. Pavlovi Z, Mileti I, Joki I, et al. The Effect of Dietary Selenium Source and Level on Hen Production and Egg Selenium Concentration[J]. Biological Trace Element Research, 2009, 131(3):263-270.

[10]. Briens M, Mercier Y, Rouffineau F, et al. 2Hydroxy-4-methylselenobutanoic acid induces additional tissue selenium enrichment in broiler chickens compared with other selenium sources.[J]. Poult, 2014, 93(1):85-93.

[11]. Attia Y A, Abdalah A A, Zeweil H S, et al. Effect of inorganic or organic selenium supplementation on productive performance, egg quality and some physiological traits of dualpurpose breeding hens[J]. Czech Journal of Animal Science, 2010, 55(11):505-519.

[12].Sahin K, Kucuk O. Effects of vitamin E and selenium on performance, digestibility of nutrients, and carcass characteristics of Japanese quails reared under heat stress $\left(34^{\circ} \mathrm{C}\right)[\mathrm{J}]$. Journal of Animal Physiology \& Animal Nutrition, 2010, 85(11-12):342-348.

[13]. Briens M, Mercier Y, Rouffineau F, et al. Comparative study of a new organic selenium source v. seleno-yeast and mineral selenium sources on muscle selenium enrichment and selenium digestibility in broiler chickens[J]. British Journal of Nutrition, 2013, 110(04):617624.
[14]. V Tufarelli, E Ceci, V Laudadio. 2-Hydroxy-4Methylselenobutanoic Acid as New Organic Selenium Dietary Supplement to Produce Selenium-Enriched Eggs[J]. Biological Trace Element Research, 2016, 171(2):453-458.

[15]. Yu J, Yao H, Gao X, et al. The Role of Nitric Oxide and Oxidative Stress in Intestinal Damage Induced by Selenium Deficiency in Chickens[J]. Biological Trace Element Research, 2015, 163(12):144-153.

[16]. Invernizzi, Guido, Agazzi, et al. Effects of inclusion of selenium-enriched yeast in the diet of laying hens on performance, eggshell quality, and selenium tissue deposition.[J]. Italian Journal of Animal Science, 2013.12(1): 131-133.

[17]. Pavlovi Z, Mileti I, Joki I, et al. The Effect of Level and Source of Dietary Selenium Supplementation on Eggshell Quality[J]. Biological Trace Element Research, 2010, 133(2):197-202.

[18]. Lipiec E, Siara G, Bierla K , et al. Determination of selenomethionine, selenocysteine, and inorganic selenium in eggs by HPLC-inductively coupled plasma mass spectrometry[J]. Analytical and Bioanalytical Chemistry, 2010, 397(2):731741.

[19]. Jlali M, Briens M, Rouffineau F, et al. Effect of 2hydroxy-4-methylselenobutanoic acid as a dietary selenium supplement to improve the selenium concentration of table eggs[J]. Journal of Animal Science, 2013, 91(4):1745-1752.

[20]. Youssefi M, Saveh I, Ghabel MR, et al. Department of Animal Science, Faculty of Agriculture, Islamic Azad University, Saveh Branch, Saveh. EFFECTS OF ORGANIC AND INORGANIC SELENIUM SUPPLEMENTS ON THE PERFORMANCE, REPRODUCTIVE, SOME BLOOD PARAMETERS AND IMMUNE SYSTEM OF BROILER BREEDERS[J]. Animal Sciences Journal, 2014. 102: 12-19.

[21]. D Yuan, Zheng L, Guo X Y, et al. Regulation of selenoprotein $\mathrm{P}$ concentration and expression by 
different sources of selenium in broiler breeders and their offspring.[J]. Poult, 2013, 92(9):23752380.

[22]. Chantiratikul A, Chinrasri O, Chantiratikul P. Effect of Sodium Selenite and Zinc-Lselenomethionine on Performance and Selenium Concentrations in Eggs of Laying Hens[J]. AsianAustralasian journal of animal sciences, 2008, 21(7):1048-1052.

[23]. Lazarus M, Orct T, Jurasovi J, et al. The effect of dietary selenium supplementation on cadmium absorption and retention in suckling rats[J]. Biometals, 2009, 22(6):973-983.

[24]. Whanger D P. Selenocompounds in Plants and Animals and their Biological Significance[J]. Journal of the American College of Nutrition, 2002, 21(3):223-232.

[25]. Surai P F. Effect of selenium and vitamin E content of the maternal diet on the antioxidant system of the yolk and the developing chick.[J]. Br Poult, 2000, 41(2):235-243.

[26]. Yuan D, Zhan X A, Wang Y X. Effect of selenium sources on the expression of cellular glutathione peroxidase and cytoplasmic thioredoxin reductase in the liver and kidney of broiler breeders and their offspring.[J]. Poult, 2012, 91(4):936-942.

\section{Cite this Article}

Myongdok Im, Hakchan Oh, Yongchol Ri, Kuangchol Kim, Dongchol Jong, Hochol Kim, "Effect of Addition of Selenium-Enriched Bean Sprouts Powder in Egg Laying Hen Feed", International Journal of Scientific Research in Science, Engineering and Technology (IJSRSET), Online ISSN : 2394-4099, Print ISSN : 2395-1990, Volume 8 Issue 3, pp. 121-128, May-June 2021. Available at doi : https://doi.org/10.32628/IJSRSET218319 